\title{
PENERAPAN MODEL PEMBELAJARAN KOOPERATIF TIPE THINK- PAIR-SHARE UNTUK MENINGKATKAN PEMAHAMAN KONSEP MASALAH SOSIAL IPS PADA SISWA SEKOLAH DASAR
}

\author{
Candra Dewi \\ Prodi PGSD FIP IKIP PGRI MADIUN \\ candra_cincun@yahoo.com
}

\begin{abstract}
The purpose of this research is: to improve understanding of social problem concept of social studies through applying cooperative learning model type think-pair-share in the students of Elementary School. This is classroom action research (CAR) with two cycles performed. Each cycles consist of four steps, there were planning, implementation of action, observation and reflection. The subjects of this research is fourth grade students in Elementary School State 2 Kedungputeri Ngawi. Data collecting techniques in this research was observation, test, interview and documentation. For data analyzing techniques was reducing data, presenting data, and taking research conclusion or verification. The research result can be conclude that there is an improvement understanding of social problem concept of social studies in fourth grade students of Elementary School State 2 Kedungputeri Ngawi. On initial conditions, the class average value is 61,31 by the number of students who complete learned is 11 students (40,74\%). In cycle I, the average value is 79,51 with students who complete learned is 22 students $(81,48 \%)$. In cycle II, the average value is 91,26 with students who complete learned is 25 students $(92,59 \%)$.
\end{abstract}

Keyword: think-pair-share teaching, understanding concept.

\begin{abstract}
Abstrak
Tujuan penelitian ini adalah untuk meningkatkan pemahaman konsep materi masalah sosial mata pelajaran IPS melalui penerapan model pembelajaran kooperatif tipe thinkpair-share pada siswa Sekolah Dasar. Penelitian ini merupakan penelitian tindakan kelas (PTK) yang dilaksanakan sebanyak dua siklus. Tiap siklus terdiri dari empat tahapan yaitu perencanaan, pelaksanaan, observasi dan refleksi. Subjek penelitian ini adalah siswa kelas IV SDN Kedungputeri 2 Ngawi. Teknik pengumpulan data menggunakan observasi, tes, wawancara, dan dokumentasi. Teknik analisis data yang digunakan adalah model analisis interaktif yang mempunyai tiga buah komponen yaitu reduksi data, penyajian data, dan penarikan kesimpulan. Berdasarkan hasil penelitian, dapat disimpulkan bahwa terdapat peningkatan pemahaman konsep materi masalah sosial mata pelajaran IPS pada siswa kelas IV SDN Kedungputeri 2 Ngawi. Pada kondisi awal ratarata kelas sebesar 61,31 dengan jumlah siswa yang tuntas belajar sebanyak 11 siswa (40,74\%). Pada siklus I nilai rata-rata kelas sebesar 79,51 dengan jumlah siswa yang tuntas belajar sebanyak 22 siswa (81,48\%). Pada siklus II rata-rata kelas sebesar 91,26 dengan jumlah siswa yang tuntas belajar sebanyak 25 siswa $(92,59 \%)$.
\end{abstract}

Kata kunci: think-pair-share, pemahaman konsep. 


\section{A. Pendahuluan}

Kegiatan belajar mengajar akan berlangsung efektif apabila siswa turut aktif dalam pembelajaran tersebut. Jadi siswa ikut memberikan pendapatnya tentang materi yang telah dipelajari. Guru juga harus memberi kesempatan pada siswa untuk bertukar pikiran dengan temannya namun disisi lain guru harus mengawasi dan mengarahkan siswa-siswanya agar terjadi timbal balik yang baik antara siswa dengan guru.

\section{Pendidikan}

Ilmu

Pengetahuan Sosial (IPS) sebagai bagian dari pendidikan umumnya memiliki peranan penting dalam peningkatan mutu pendidikan, khususnya di dalam menghasilkan peserta didik yang mampu berinteraksi antara siswa yang satu dengan siswa yang lainnya.

Dalam pembelajaran IPS guru hendaknya menciptakan pembelajaran sesuai dengan kondisi dan perkembangan potensi siswa dan menyadari bahwa belajar merupakan kegiatan aktif siswa dalam membangun makna atau pemahaman agar pembelajaran yang dilakukan benar-benar berguna dan bermanfaat bagi siswa.

Berdasarkan hasil observasi awal yang dilakukan di SDN Kedungputeri 2 Kecamatan Paron Kabupaten Ngawi khususnya kelas IV tahun pelajaran untuk mata pelajaran IPS materi masalah sosial menunjukan hasil yang rendah. Hal ini dapat dilihat dari nilai tes masalah sosial yag dilaksanakan oleh guru kelas IV SDN Kedungputeri 2 Ngawi sebelum peneliti melaksanakan tindakan.

Permasalahan pembelajaran di atas memerlukan pemecahan masalah. Alternatif pemecahannya yaitu pembelajaran IPS dengan menggunakan model pembelajaran yang tepat. Model pembelajaran yang tepat itu harus memuat metode dan media yang relevan dengan materi pembelajaran IPS. Salah satu model pembelajaran yang menunjang dalam materi IPS dan membantu siswa memahami konsep pembelajaran adalah model pembelajaran kooperatif tipe think-pairshare yang dikembangkan oleh Frank Lyman (1985) dan rekan-rekannya. Think-pair-share merupakan model pembelajaran yang memberi kesempatan siswa untuk dapat berinteraksi, berdiskusi, bertukar pendapat dan mengekspresikan ide-idenya secara lebih leluasa dengan temannya bahkan kepada guru.

Ketika mempelajari suatu hal tidak hanya memerlukan pengetahuan saja untuk mengerti maksud dari hal yang dipelajari, namun juga harus memerlukan pemahaman tentang sesuatu yang dipelajari tersebut. Menurut Suhaenah Suparno (2001: 7), pemahaman didefinisikan sebagai kemampuan untuk menangkap arti dari apa yang tersaji, kemampuan untuk menterjemahkan dari satu bentuk ke bentuk yang lain dalam kata-kata, angka, 
maupun interpretasi berbentuk penjelasan, ringkasan, prediksi dan hubungan sebab akibat.

Pemahaman termasuk salah satu ranah kognitif dalam taksonomi Bloom. Pemahaman dapat dibedakan ke dalam tiga kategori (Nana Sudjana, 2011: 24), yaitu: (1) Pemahaman terjemahan, mulai dari terjemahan dalam arti sebenarnya. (2) Pemahaman penafsiran, menghubungkan bagian-bagian terdahulu dengan yang diketahui berikutnya, membedakan yang pokok dan yang bukan pokok. (3) Pemahaman ekstrapolasi, mampu melihat dibalik yang tertulis, membuat ramalan tentang konsekuensi atau memperluas persepsi dalam arti waktu, dimensi, kasus ataupun masalah.

Setiap mata pelajaran perlu dipahami secara mendalam oleh setiap siswa termasuk dalam mempelajari IPS. Pemahanam tersebut mencakup pemahaman konsep dari setiap materi pelajaran yang diberikan agar siswa dapat menerima materi dengan baik. Menurut Trianto (2009: 7), pemahaman konsep adalah pemahaman siswa terhadap dasar kualitatif dimana fakta-fakta saling berkaitan dengan kemampuannya untuk menggunakan pengetahuan tersebut dalam situasi baru. Setelah siswa memperoleh apa yang mereka ketahui kemudian mereka mampu memanfaatkan pengetahuan tersebut dalam situasi baru dan ini membuat siswa paham benar tentang pengetahuan yang diperolehnya.

IPS adalah bidang studi yang mempelajari, menelaah, menganalisis gejala dan masalah sosial di masyarakat dengan meninjau dari berbagai aspek kehidupan atau satu perpaduan (Sardjiyo dkk, 2008: 1.26). IPS bukanlah sesuatu yang berdiri sendiri melainkan suatu perpaduan dan IPS juga tidak lepas dari kehidupan masyarakat sehari-harinya. Mulyono Tj. dalam Hidayati dkk (2008: 1.7) memberi batasan IPS adalah merupakan suatu pendekatan interdisipliner (inter-diciplininary approach) dari pelajaran ilmu-ilmu sosial. Pendapat ini menyatakan bahwa IPS terdiri dari beberapa ilmu sosial. Walaupun di SD terdapat mata pelajaran IPS namun di dalamnya terdapat beberapa ilmu sosial yang juga harus dipelajari. IPS merupakan integrasi dari berbagai cabang ilmu-ilmu sosial seperti sosiologi, anthropologi budaya, psikologi sosial, sejarah, geografi, ekonomi, ilmu politik, dan sebagainya.

Pada dasarnya tujuan dari pendidikan IPS adalah untuk mendidik dan memberi bekal kemampuan dasar kepada siswa untuk mengembangkan diri sesuai dengan bakat, minat, kemampuan dan lingkungannya, serta berbagai bekal bagi siswa untuk melanjutkan pendidikan kejenjang yang lebih tinggi (Etin Solihatin dan Raharjo, 2007: 15).

Salah satu kompetensi pada mata pelajaran IPS yang dipelajari oleh siswa kelas IV adalah masalah sosial. Masalah 
sosial adalah sebuah gejala atau fenomena yang muncul dalam realitas kehidupan bermasyarakat (Soetomo, 2010: 28). Menurut Weinberg dalam Soetomo (2010: 7) masalah sosial adalah situasai yang dinyatakan sebagai sesuatu yang bertentangan dengan nilainilai oleh warga masyarakat yang cukup signifikan, dimana mereka sepakat dibutuhkannya suatu tindakan untuk mengubah situasi tersebut.

$$
\text { Setiap pelaksanaan }
$$
pembelajaran perlu menggunakan model pembelajaran tertentu agar pelaksanaannya dapat berjalan secara maksimal. Model pembelajaran adalah pola yang digunakan sebagai pedoman dalam merencanakan pembelajaran di kelas maupun tutorial. Salah satu model pembelajaran yang dapat digunakan adalan model pembelajaran kooperatif. Anita Lie (2008: 150) menyebutkan pembelajaran kooperatif dengan istilah pembelajaran gotong-royong, yaitu kelompok pembelajaran yang memberi kesempatan kepada peserta didik untuk bekerjasama dengan siswa lain dalam tugas-tugasnya yang terstruktur.

Langkah-langkah model pembelajaran kooperatif menurut Agus Suprijono, (2009: 65) ditunjukkan pada tabel 1.

Tabel 1. Langkah-langkah Model Pembelajaran Kooperatif

\section{FASE-FASE}

\begin{tabular}{|c|c|}
\hline $\begin{array}{l}\text { Fase 1: Present goals and set } \\
\text { Menyampaikan tujuan dan } \\
\text { mempersiapkan siswa. }\end{array}$ & $\begin{array}{l}\text { Menjelaskan tujuan pembelajaran } \\
\text { mempersiapkan siswa agar lebih } \\
\text { menerima pelajaran. }\end{array}$ \\
\hline $\begin{array}{l}\text { Fase 2: Present information } \\
\text { Menyajikan informasi. }\end{array}$ & $\begin{array}{l}\text { Mempresentasikan informasi kepada siswa } \\
\text { secara verbal. }\end{array}$ \\
\hline $\begin{array}{l}\text { Fase 3: Organize students into } \\
\text { learning tems } \\
\text { Mengorganisir siswa ke dalam } \\
\text { tim-tim belajar. }\end{array}$ & $\begin{array}{l}\text { Memberikan penjelasan kepada siswa } \\
\text { tentang tata cara pembentukan tim belajar } \\
\text { dan membantu kelompok melakukan transisi } \\
\text { yang efisien. }\end{array}$ \\
\hline $\begin{array}{l}\text { Fase 4: Assist team work and } \\
\text { study. Membantu kerja tim dan } \\
\text { belajar. }\end{array}$ & $\begin{array}{l}\text { Membentuk tim-tim belajar selama siswa } \\
\text { mengerjakan tugas. }\end{array}$ \\
\hline $\begin{array}{l}\text { Fase 5: Test on the materials } \\
\text { Mengevaluasi }\end{array}$ & $\begin{array}{l}\text { Menguji pengetahuan siswa mengenai } \\
\text { mengenai materi pelajaran atau kelompok- } \\
\text { kelompok mempresentasikan hasil kerjanya. }\end{array}$ \\
\hline $\begin{array}{l}\text { Fase 6: Provide Recognition } \\
\text { Memberikan pengakuan atau } \\
\text { penghargaan }\end{array}$ & $\begin{array}{l}\text { Mempersiapkan cara untuk mengakui usaha } \\
\text { dan prestasi individu maupun kelompok. }\end{array}$ \\
\hline
\end{tabular}

\section{PERILAKU GURU}


Pembelajaran kooperatif
memiliki tipe-tipe tertentu,
walaupun prinsip dasar dari
pembelajran kooperatif ini tidak
berubah yaitu bekerja bersama
untuk mencapai tujuan tertentu. Salah satu tipe pembelajaran kooperatif yang sederhanada bermanfaat adalah tipe think-pairshare. Think-pair-share atau berpikir bepasangan berbagi menurut Trianto (2007: 61) adalah jenis pembelajaran kooperatif yang dirancang untuk mempengaruhi pola interaksi siswa. Namun thinkpair-share tidak hanya mempengaruhi pola interaksi tetapi juga pola pemikiran siswa terhadap sesuatu karena dalam teknik ini siswa akan saling bertukan pikiran dengan temannya. Teknik thinkpair-share memberi siswa kesempatan untuk bekerja sama dengan orang lain. Keunggulan dari teknik ini adalah optimaliasasi partisipasi siswa, yaitu memberi kesempatan delapan kali lebih banyak kepada setiap siswa untuk dikenali dan menunjukkan partisipasi mereka kepada orang lain.

Pembelajarn koperatif tipe think-pair-share memiliki langkahlangkah pembelajaran tertentu. Menurut Richard Arends (2008: 11) langkah pembelajarn kooperatif antara lain: (1) berpikir (thinking), guru mengajukan suatu pertanyaan atau masalah yang berhubungan dengan materi yang akan disampaikan, kemudian meminta waktu siswa beberapa menit memikirkan sendiri jawaban atau masalah tersebut, (2) berpasangan (pairing), guru meminta siswa untuk berdiskusi secara berpasangan berpasangan mendiskusikan apa yang telah mereka peroleh, (3) berbagi (sharing), guru meminta pasangan-pasangan untuk berbagi dengan keseluruhan kelas yang telah mereka bicarakan.

\section{B. Metodologi Penelitian}

Penelitian ini dilaksanakan di SDN Kedungputeri 2 Kecamatan Paron Kabupaten Ngawi. Waktu penelitian ini dilaksanakan pada semester genap tahun ajaran 2013/2014 dengan jangka waktu selama 5 bulan yaitu dari bulan Januari hingga bulan Mei 2014. Subjek penelitian ini adalah siswa kelas IV SDN Kedungputeri 2 Kecamatan Paron Kabupaten Ngawi tahun pelajaran 2013/2014 semester genap sebanyak 27 siswa. Berdasarkan masalah yang diteliti, mengenai perbaikan proses yang dilakukan di dalam kelas maka bentuk penelitian yang tepat untuk digunakan adalah Penelitian Tindakan Kelas (PTK).

Strategi yang dilakukan dalam penelitian adalah model siklus. PTK dilaksanakan dalam bentuk siklus berulang yang di dalamnya terdapat empat tahapan utama kegiatan, yaitu (1) perencanaan; (2) pelaksanaan tindakan; (3) pengamatan; dan (4) refleksi. Sumber data atau informasi yang digunakan dalam penelitian ini terdiri dari sumber data primer (siswa kelas IV 
dan guru kelas IV) dan sumber data sekunder (arsip atau dokumen siswa kelas IV, rencana pembelajaran dan tes hasil belajar siswa.). Teknik analisis data yang digunakan dalam penelitian ini adalah teknik analisis interaktif. Teknik analisis interaktif ini mempunyai tiga komponen pokok yaitu: (1) reduksi data, (2) penyajian data, (3) penarikan simpulan atau verifikasi.

Prosedur penelitian tindakan kelas ini terdiri dari 2 siklus. Tiap siklus dilaksanakan sesuai dengan perubahan yang dicapai. Dari kegiatan tersebut didapat refleksi awal. Berpedoman pada refleksi awal tersebut, maka prosedur pelaksanaan penelitian tindakan kelas ini meliputi perencanaan, pelaksanaan tindakan, observasi dan refleksi dalam setiap siklus.

\section{Hasil Penelitian dan Pembahasan}

Sebelum melaksanakan proses penelitian, peneliti melakukan observasi dan wawancara untuk mengetahui kondisi nyata di lapangan serta mencari informasi dan menemukan berbagai kendala yang dihadapi sekolah dalam proses pembelajaran IPS khususnya kelas IV. Hasil tes pembelajaran IPS materi masalah sosial siswa kelas IV sebelum tindakan dapat dilihat pada tabel 2.

Tabel 2. Frekuensi Nilai Tes Pembelajaran IPS Materi Materi Masalah Sosial Siswa Kelas IV SDN Kedungputeri 2 Ngawi Tahun Pelajaran 2013/2014 Sebelum Tindakan.

\begin{tabular}{ccccccc}
\hline No & $\begin{array}{c}\text { Interval } \\
\text { Nilai }\end{array}$ & $\begin{array}{c}\text { Frekuensi Nilai Tengah } \\
(\mathbf{f i})\end{array}$ & Fi(xi) & $\begin{array}{c}\text { Persentase } \\
(\mathbf{\%})\end{array}$ & Keterangan \\
\hline 1. & $20-33$ & 4 & 26,5 & 106 & 14,81 & Di bawah KKM \\
\hline 2. & $34-47$ & 3 & 40,5 & 121,5 & 11,11 & Di bawah KKM \\
\hline 3. & $48-61$ & 9 & 54,5 & 490,5 & 33,33 & Di bawah KKM \\
\hline 4. & $62-75$ & 2 & 68,5 & 139 & 7,41 & Di atas KKM \\
\hline 5. & $76-89$ & 5 & 82,5 & 412,5 & 18,52 & Di atas KKM \\
\hline 6. & $90-103$ & 4 & 96,5 & 386 & 14,81 & Di atas KKM \\
\hline \multicolumn{2}{l}{ Jumlah } & 27 & & 1655,5 & 100 & \\
\hline
\end{tabular}

Nilai rata-rata $=1655,5: 27=61,31$

Ketuntasan klasikal $=11: 27 \times 100 \%=40,74 \%$

Nilai di bawah KKM $=16: 27 \times 100 \%=59,26 \%$

Nilaitertinggi $=100$

Nilaiterendah $=20$

Hasil tes di atas menunjukkan sebagian besar siswa belum mencapai ketuntasan belajar.Siswa yang memperoleh nilai di atas KKM (tuntas belajar) sebanyak 11 siswa $(40,74 \%)$, sedangkan siswa yang memperoleh nilai di bawah KKM (tidak tuntas belajar) sebanyak 16 siswa $(59,26 \%)$. Pemahaman konsep materi masalah sosial yang rendah ini perlu di atasi agar meningkat yaitu dengan cara 
menerapkan model pembelajaran kooperatif tipe think-pair-share. Sehubungan dengan hasil tes tersebut maka perlu dilakukan tindakan untuk meningkatkan kemampuan siswa dalam memahami konsep materi masalah sosial dengan mengadakan penelitian di kelas IV SDN Kedungputeri 2 menggunakan model pembelajaran kooperatif tipe think-pai- share (TPS).

\section{Deskripsi Siklus I}

Tindakan siklus I dilaksanakan selama dua kali pertemuan. Setiap pertemuan terdiri dari dua jam pelajaran (2x35 menit). Siklus I dilaksanakan selama dua minggu. Siklus I terdiri dari 4 tahap yaitu tahap perencanaan, tahap peaksanaan tindakan, tahap observasi dan tahap refleksi. Pada siklus I ini, peneliti menetapkan indikator kerja sebesar $80 \%$ (21 siswa) dari jumlah siswa seluruhnya yaitu 27 siswa memperoleh nilai $\geq 70$. Berikut merupakan tabel distribusi frekuensi penilaiaan hasil pemahaman konsep materi masalah sosial yang dapat dilihat pada tabel sebagai berikut:

Tabel 3. Frekuensi NilaiPemahaman Konsep Materi Masalah Sosial IPS Melalui Penerapan Model Pembelajaran Kooperatif Tipe Think-Pair-Share Siswa Kelas IV SDN Kedungputeri 2 Ngawi Tahun Pelajaran 2013/2014 pada Siklus I.

\begin{tabular}{ccccccc}
\hline No & $\begin{array}{c}\text { Interval } \\
\text { Nilai }\end{array}$ & $\begin{array}{c}\text { Frekuensi } \\
(\mathbf{f i})\end{array}$ & $\begin{array}{c}\text { Nilai } \\
\text { Tengah }(\mathbf{x i})\end{array}$ & Fi(xi) & $\begin{array}{c}\text { Persentase } \\
(\mathbf{\%})\end{array}$ & Keterangan \\
\hline 1. & $35-45$ & 2 & 40 & 80 & 7,4 & Di bawah KKM \\
\hline 2. & $46-56$ & 1 & 51 & 51 & 3,7 & Di bawah KKM \\
\hline 3. & $57-67$ & 2 & 62 & 124 & 7,4 & Di bawah KKM \\
\hline 4. & $68-78$ & 5 & 73 & 365 & 18,52 & Di atas KKM \\
\hline 5. & $79-89$ & 8 & 84 & 672 & 29,63 & Di atas KKM \\
\hline 6. & $90-100$ & 9 & 95 & 855 & 33,33 & Di atas KKM \\
\hline \multicolumn{2}{c}{ Jumlah } & 27 & & 2147 & 100 & \\
\hline
\end{tabular}

Nilai rata-rata $=2147: 27=79,52$

Ketuntasan klasikal $=22: 27 \times 100 \%=81,48 \%$

\begin{tabular}{l}
\hline Nilai di bawah $\mathrm{KKM}=5: 27 \times 100 \%=18,52 \%$ \\
\hline Nilai tertinggi $=100$ \\
\hline Nilai terendah $=35$
\end{tabular}

Rata-rata nilai pemahaman konsep materi masalah sosial siswa pada siklus I adalah 79,52 $(81,48 \%)$. Apabila dibandingkan dengan nilai pada kondisi awal sebelum tindakan, nilai rata-rata kelas yang semula 61,31 meningkat menjadi 79,48. Jumlah siswa yang nilainya sudah mencapai KKM 70 juga mengalami peningkatan yaitu dari 11 siswa atau 40,74\% meningkat menjadi 22 atau 81,48\%. Rata-rata kelas 
meningkat sebesar 18,21 sedangkan siswa yang tuntas mengalami peningkatan sebesar $40,74 \%$.

Setelah menganalisis kekurangan dalam pelaksanaan pembelajaran pada siklus I, peneliti bersama guru kelas mencari solusi untuk mengatasi kekurangan tersebut. Solusi yang digunakan untuk mengatasi masalah tersebut antara lain: (1) guru lebih memperhatikan siswa secara keseluruhan sehingga pembelajaran berjalan dengan kondusif, (2) guru melakukan umpan balik untuk meningkatkan pemahaman konsep materi masalah sosial siswa, (2) guru memperjelas ketika menyampaikan materi sehingga siswa mengerti materi tersebut, (2) guru membentuk kelompok yang lebih besar.

Berdasarkan analisis tersebut, peneliti perlu melanjutkan penelitian pada siklus II untuk memperbaiki hasil belajar dan meningkatkan pemahaman konsep materi masalah sosial pada siswa.

\section{Deskripsi Siklus II}

Berdasarkan hasil tes yang dilakukan pada pertemuan kedua siklus II, diperoleh nilai hasil pemahaman konsep materi masalah sosial sebagai berikut:

Tabel 4. Frekuensi Penilaian Hasil Pemahaman Konsep Materi Masalah Sosial Melalui Penerapan Model Pembelajaran Kooperatif Tipe Think-PairShareSiswa Kelas IV SDN Kedungputeri 2 Ngawi Tahun Pelajaran 2013/2014 pada Siklus II.

\begin{tabular}{ccccccc}
\hline No & $\begin{array}{c}\text { Interval } \\
\text { Nilai }\end{array}$ & $\begin{array}{c}\text { Frekuensi } \\
\text { (fi) }\end{array}$ & $\begin{array}{c}\text { Nilai } \\
\text { Tengah (xi) }\end{array}$ & Fi(xi) & $\begin{array}{c}\text { Persentase } \\
(\mathbf{\%})\end{array}$ & Keterangan \\
\hline 1. & $60-66$ & 2 & 63 & 126 & 7,4 & Di Bawah KKM \\
\hline 2. & $67-73$ & 1 & 70 & 70 & 3,7 & Di AtasKKM \\
\hline 3. & $74-80$ & 1 & 77 & 77 & 3,7 & Di Atas KKM \\
\hline 4. & $81-87$ & 3 & 84 & 252 & 11,11 & Di Atas KKM \\
\hline 5. & $88-94$ & 3 & 91 & 273 & 11,11 & Di Atas KKM \\
\hline 6. & $95-101$ & 17 & 98 & 1666 & 62,96 & Di Atas KKM \\
\hline & & 27 & & 2464 & 100 & \\
\hline
\end{tabular}

Nilai rata-rata $=2464: 27=91,26$

Ketuntasan klasikal $=25: 27 \times 100 \%=92,59 \%$

Nilai di bawah $\mathrm{KKm}=2: 27 \times 100 \%=7,4 \%$

Nilai tertinggi $=100$

Nilai terendah $=60$

Dari tabel 4 dapat dilihat nilai rata-rata siswa yaitu 91,26 dan siswa yang sudah mencapai KKM 70 sebanysk 25 siswa
(92,59\%). Apabila dibandingkan dengan nilai siklus I, nilai rata-rata kelas meningkat dari 79,52 menjadi 91,26. Sedangkan siswa yang mencapai KKM 
pada siklus I berjumlah 22 siswa $(81,48 \%)$ siswa, meningkat menjadi 25 siswa $(92,59 \%)$ pada siklus II. Peningkatan nilai ratarata antara siklus I dan siklus II sebesar 11,74 sedangkan peningkatan siswa yang mencapai KKM yang terjadi dari siklus I ke siklus II sebesar 11,11\%.

Berdasarkan hasil penelitian di atas dapat diketahui bahwa terjadi peningkatan pemahaman konsep pembelajaran IPS materi masalah sosial pada siswa kelas IV SDN Kedungputeri 2 Ngawi setelah melakukan penerapan model pembelajaran kooperatif tipe think-pair-share. Perbandingan nilai tertinggi dan nilai terendah siswa SDN Kedungputeri 2 Ngawi pada kondisi awal sebelum tindakan dan setelah tindakan siklus I dan Siklus II dapat dilihat pada tabel sebagai berikut:

Tabel 5. Rekapitulasi Nilai Tertinggi dan Nilai Terendah Hasil Pemahaman Konsep Materi Masalah Sosial Melalui Penerapan Model Pembelajaran Kooperatif Tipe Think-Pair-ShareSiswa Kelas IV SDN Kedungputeri 2 Ngawi Tahun Pelajaran 2013/2014 pada Kondisi Awal, Siklus I dan Siklus II

\begin{tabular}{lccc}
\hline \multirow{2}{*}{$\begin{array}{c}\text { Pembelajaran IPS } \\
\text { materi Masalah Sosial }\end{array}$} & $\begin{array}{c}\text { Kondisi Awal } \\
\text { Sebelum Tindakan }\end{array}$ & \multicolumn{2}{c}{$\begin{array}{c}\text { Setelah Dilaksanakan } \\
\text { Tindakan }\end{array}$} \\
\cline { 3 - 4 } NilaiTerendah & 20 & Siklus I & Siklus II \\
\hline NilaiTertinggi & 100 & 35 & 60 \\
\hline
\end{tabular}

Dari tabel 4, rekapitulasi nilai tertinggi dan nilai terendah hasil pemahaman konsep materi masalah sosial siswa kelas

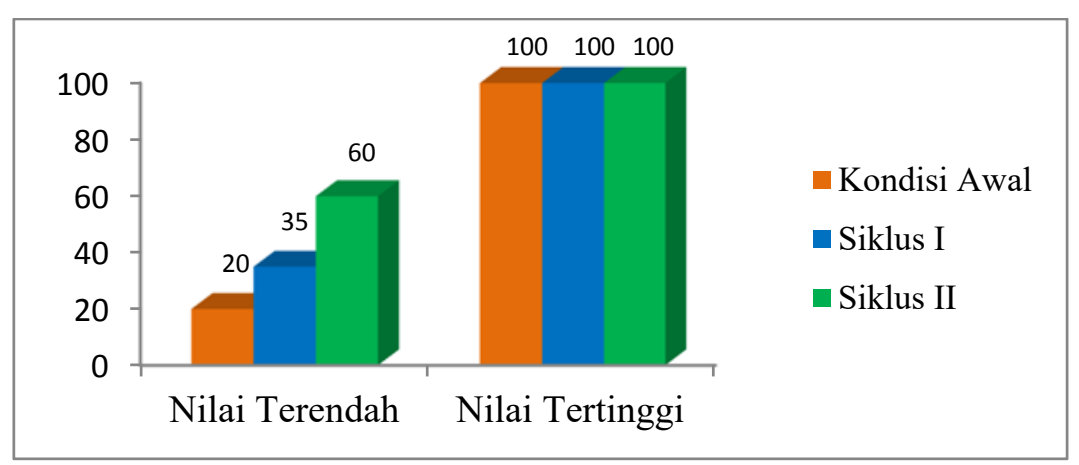

Gambar 1. Grafik Perbandingan Nilai Tertinggi dan Nilai Terendah Hasil Pemahaman Konsep Materi Masalah Sosial Siswa Kelas IV SDN Kedungputeri 2 Ngawi pada Kondisi Awal, Siklus I dan Siklus II. 
Berdasarkan tabel 4 dan gambar 1 dapat dijelaskan sebagai berikut: nilai terendah siswa meningkat dari 20 pada kondisi awal menjadi 35 pada siklus I dan meningkat lagi pada siklus II sebesar 60.Pada kondisi awal, siklus I dan siklus II nilai tertingginya yaitu 100 .

Nilai rata-rata hasil pemahaman konsep materi masalah sosial pada kondisi awal sebelum tindakan dan setelah tindakan siklus I dan siklus II dapat dilihat pada tabel 7 berikut.

Tabel 5. Rekapitulasi Rata-rata Nilai Hasil Pemahaman Konsep Materi Masalah Sosial Melalui Penerapan Model Pembelajaran Kooperatif Tipe ThinkPair-ShareSiswa Kelas IV SDN Kedungputeri 2 Ngawi Tahun Pelajaran 2013/2014 pada Kondisi Awal, Siklus I dan Siklus II

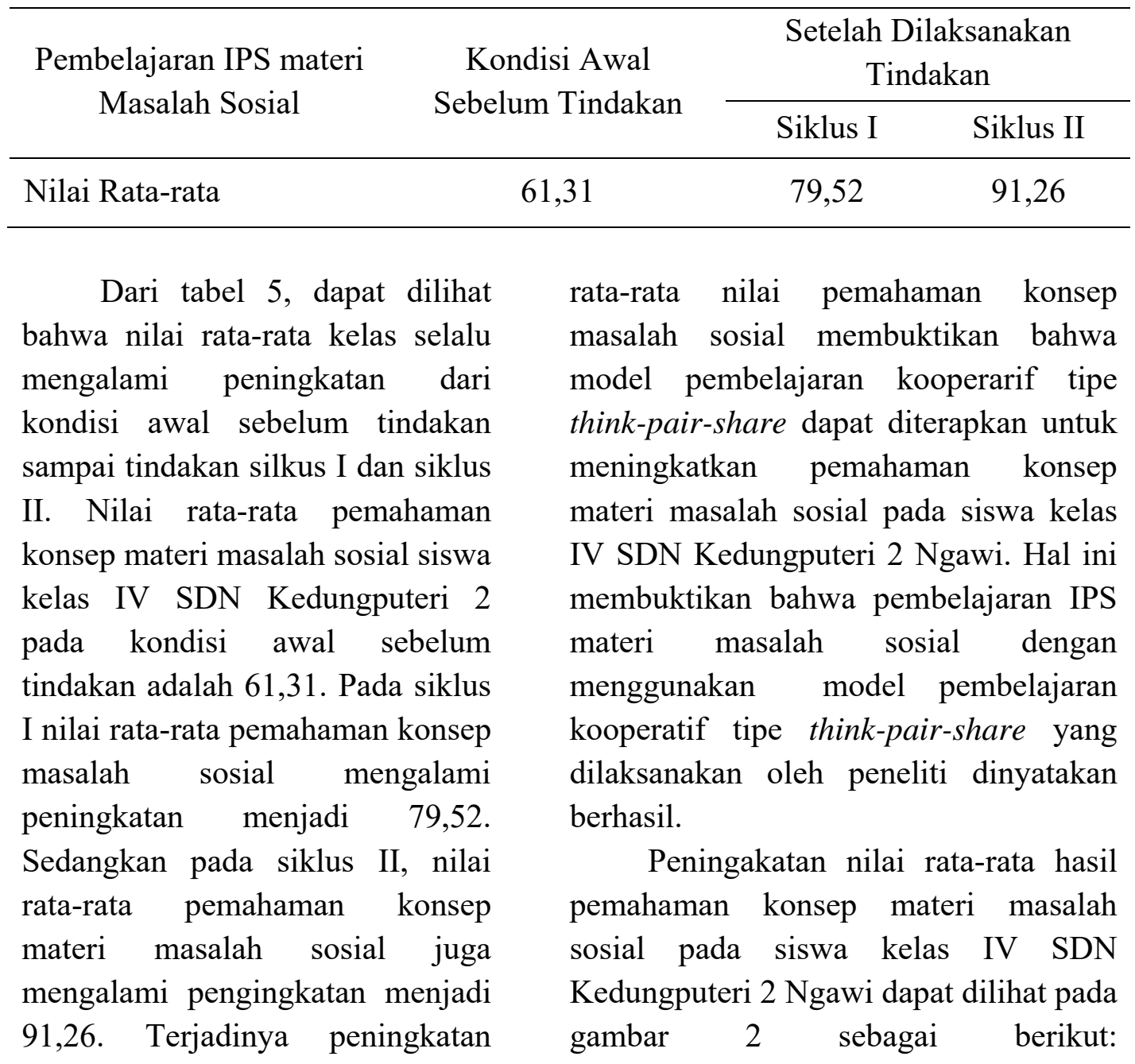




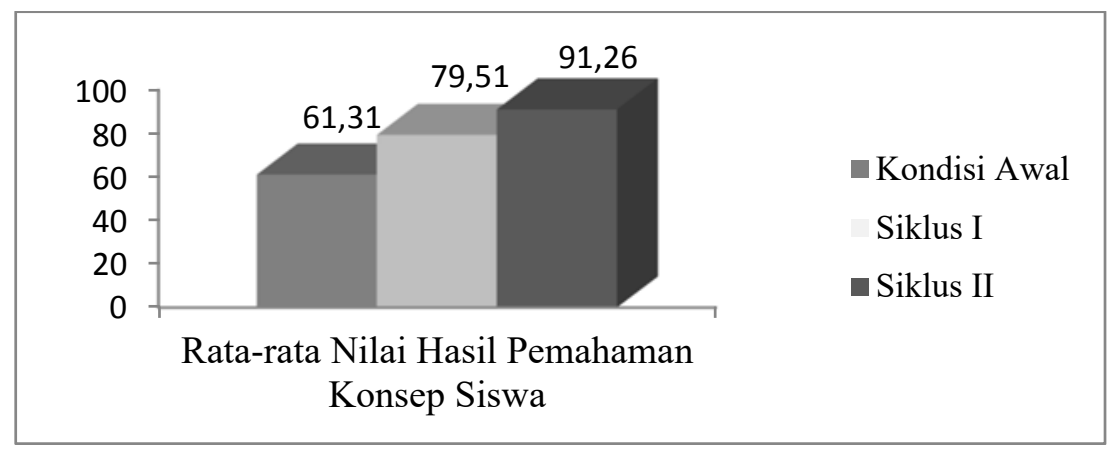

Gambar 2. Grafik Peningkatan Nilai Rata-rata Hasil Pemahaman Konsep Materi Masalah Sosial Melalui Penerapan Model Pembelajaran Kooperatif Tipe Think-Pair-ShareSiswa Kelas IV SDN Kedungputeri 2 Ngawi Tahun Pelajaran 2013/2014 pada Kondisi Awal, Siklus I dan Siklus II.

Jumlah siswa yang awal, siklus I, dan Siklus II apabila mengalami ketuntasan belajar dibandingkan dapat dilihat pada tabel materi masalah sosial pada kondisi sebagai berikut:

Tabel 6. Rekapitulasi Ketuntasan Belajar Materi Masalah Sosial Melalui Penerapan Model Pembelajaran Kooperatif Tipe Think-PairShareSiswa Kelas IV SDN Kedungputeri 2 Ngawi Tahun Pelajaran 2013/2014 pada Kondisi Awal, Siklus I, dan Siklus II.

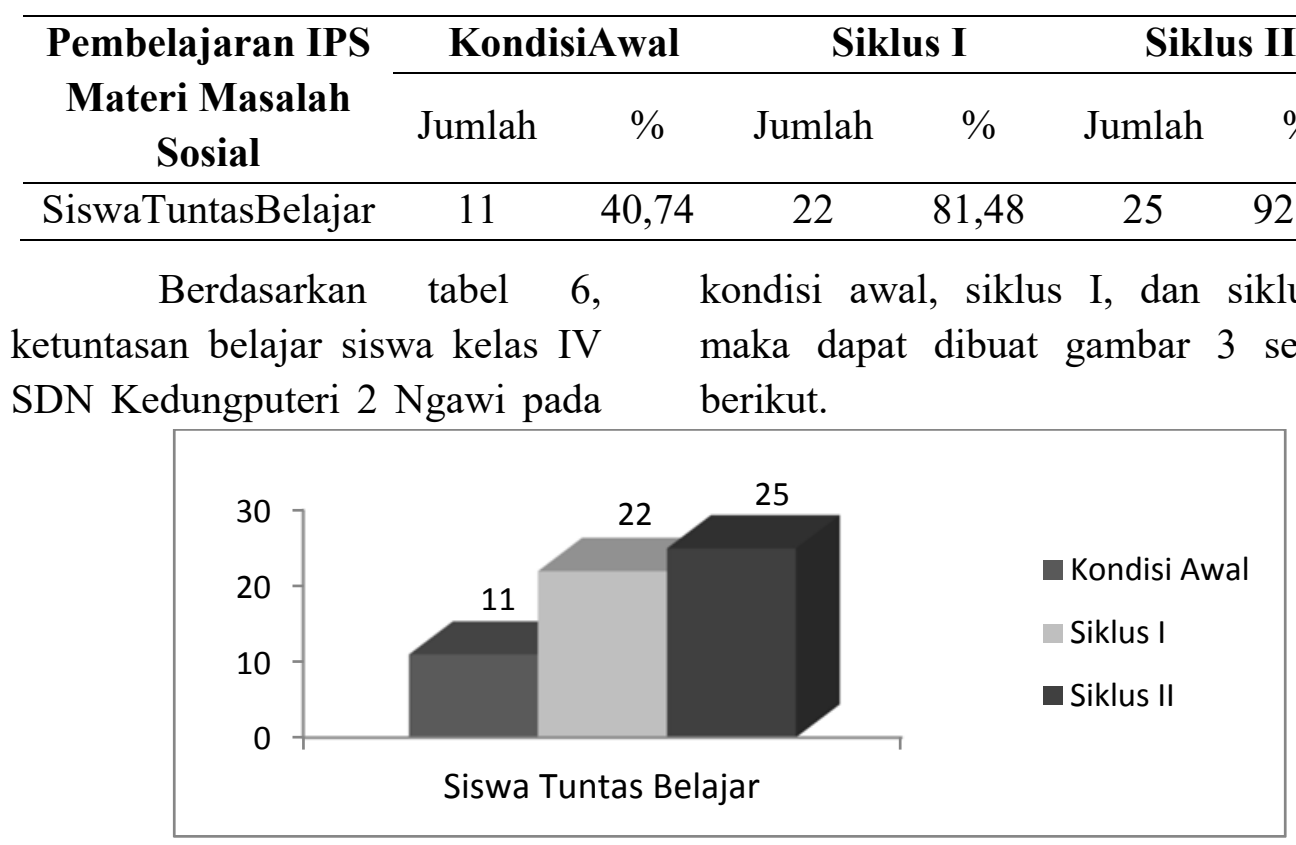

Gambar 3. Grafik Peningkatan Ketuntasan Pembelajaran Pemahaman Konsep Materi Masalah Sosial Melalui Penerapan Model Pembelajaran Kooperatif Tipe Think-Pair-ShareSiswa Kelas IV SDN Kedungputeri 2 Ngawi Tahun Pelajaran 2013/2014 pada Kondisi Awal, Siklus I dan Siklus II. 
Pada tabel 6, Prosentase ketuntasan meningkat, dari jumlah siswa yang tuntas belajar pada konsidisi awal sebanyak 11 siswa $(40,74 \%)$ menjadi 22 siswa $(81,48 \%)$ dan pada siklus II meningkat lagi menjadi 25 siswa $(92,59 \%)$.

Berdasarkan tabel 6 dan gambar 3 diatas, dapat diketahui bahwa penerapan model pembelajaran kooperatif tipe thinkpair-share pada pembelajaran IPS materi masalah sosial siswa kelas IV SDN Kedungputeri 2 Ngawi dapat meningkatkan pemahaman konsep dan ketuntasan hasil belajar materi masalah sosial siswa. Maka dapat dikatakan dengan menerapakan model pembelajaran kooperatif tipe think-pair-share dapat meningkatkan pemahaman konsep siswa materi masalah sosial pada siswa kelas IV SDN Kedungputeri 2 Ngawi.

\section{Simpulan dan Saran}

Berdasarkan hasil penelitian tindakan kelas yang dilaksanakan dalam dua siklus tersebut dapat disimpulkan bahwa penerapan model pembelajaran kooperatif tipe think-pair-share dapat meningkatkan pemahaman konsep IPS materi masalah sosial pada siswa kelas IV SDN Kedungputeri 2 Ngawi Tahun Pelajaran 2011/2012. Hal ini dibuktikan dengan adanya peningkatan jumlah siswa yang mencapai nilai ketuntasan belajar (KKM) yang sudah ditentukan sekolah yaitu 70. Ketuntasan pembelajaran pada kondisi awal sebelum tindakan terdapat 11 siswa $(40,74 \%)$ meningkat menjadi 22 siswa $(81,48 \%)$ pada siklus I, itu menunjukkan ada peningkatan sebesar 40,67\%. Dan meningkat menjadi 24 siswa $(88,46 \%)$ pada siklus II, apabila dibandingkan dengan siklus I mengalami peningkatan sebesar $6,98 \%$. Nilai rata-rata tiap siklus juga mengalami peningkatan, pada kondisi awal nilai rata-ratanya yaitu 61,31 menjadi 80 pada siklus I dan meningkat menjadi 91 pada siklus II. Hal ini dapat disimpulkan bahwa langkahlangkah pembelajaran kooperatif tipe think-pair-share yang dapat meningkatkan pemahaman konsep materi masalah sosial siswa. Dengan demikian penerapan model pembelajaran kooperatif tipe think-pair-share dapat digunakan untuk meningkatkan pemahaman konsep materi masalah sosial pada siswa kelas IV SDN Kedungputeri 2 Ngawi tahun pelajaran 2011/2012 karena model pembelajaran kooperatif tipe think-pair-share merupakan model pembelajaran yang menyenangkan, bekerja secara kelompok tetapi lebih menekankan pada kemampuan individu setiap individu

Berdasarkan simpulan di atas, maka peneliti memberikan saran-saran khususnya pada SDN Kedungputeri 2 Ngawi untuk mengupayakan pelatihan bagi guru untuk dapat mendukung pelaksanaan pembelajaran agar tujuan pembelajaran dapat tercapai sesuai dengan harapan. Dengan adanya pelatihan bagi guru maka guru dapat memilih model pembelajaran yang sesuai dengan model pembelajaran. Salah satu modelnya adalah model pembelajaran kooperatif tipe think-pairshare. 


\section{DAFTAR PUSTAKA}

Abdurrahmat Fathoni. 2006. Metodologi Penelitian dan Teknik Penyusunan Skripsi. Jakarta: Rineka Cipta.

Agus 2009. Cooperative Learning: Teori dan Apikasi PAIKEM. Yogyakarta: Pustaka Pelajar.

Anita Lie. 2005. Cooperative Learning. Jakarta: Gramedia.

Etin Solihatin \& Raharjo. 2009. Kooperatif Learning Analisis Model Pembelajaran IPS. Jakarta. Bumi Aksara.

Faqih Samlawi \& Bunyamin Maftuh.2001. Konsep Dasar IPS. Bandung: Maulana.

Hidayati, Mujinem \& Anwar Senen. 2008. Pengembangan Pendidikan IPS SD. Surakarta: Konsorsium PJJ SI PGSD

Tantya Hisnu P. \& Winardi. 2008. Ilmu Pengetahuan Sosial untuk SD/MI Kelas IV. Jakarta: Pusat Perbukuan, Departemen Pendidikan Nasional.

Isjoni. 2010. Pembelajaran Kooperatif. Jakarta. Gramedia.

Miftahul Huda. 2011. Cooperative Learning. Yogyakarta: Pustaka Pelajar.
Milles \& Huberman. 2009. Analisis Data Kualitatif. Jakarta: Universitas Indonesia (UI-Press)

Nana Sudjana. 2011. Penilaian Hasil Belajar Proses Belajar Mengajar. Bandung: Remaja Rosdakarya

Oemar Hamalik. 2010. Perencanaan Pengajaran Berdasarkan Pendekatan Sistem. Jakarta: Bumi Aksara.

Richard Arends. 2008. Learning To Teach. Yogyakarta: Pustaka Pelajar.

Sapriya. 2009. Pendidikan IPS. Bandung: Remaja Rosdakarya.

Sardjiyo, Didih Sugandi dan Ischak. 2008. Pendidikan IPS di SD. Jakarta: Universitas Terbuka

Sarwiji Suwandi. 2008. Penelitian Tindakan Kelas (PTK) dan Penelitian Karya Ilmiah. Surakarta: Panitia Sertifikasi Rayon Guru 13

Sugiyanto. 2009. Model-Model Pembelajaran Inovatif. Surakarta: Panitia Sertifikasi Guru Rayon 13 FKIP UNS Surakarta.

Suharsimi Arikunto. 2010. Dasar-dasar Evaluasi Pendidikan. Jakarta: Bumi Aksara.

Syaiful Sagala. 2003. Konsep dan Makna Pembelajaran. Bandung: CV Alfabeta

Trianto. 2010. Mendesain Model Pembelajaran Inovatif Progresif. Jakarta: Kencana. 